\title{
Staphylococcus felis, a New Species from Clinical Specimens from Cats
}

\author{
SHIZUNOBU IGIMI, ${ }^{1 *}$ SEIJI KAWAMURA, ${ }^{1}$ EIJI TAKAHASHI, ${ }^{2}$ AND TOMOTARI MITSUOKA ${ }^{1}$ \\ Department of Biomedical Science, ${ }^{1}$ and Department of Veterinary Microbiology, ${ }^{2}$ Faculty of Agriculture, The University \\ of Tokyo, Tokyo 113, Japan
}

\begin{abstract}
A new species, Staphylococcus felis, was isolated from clinical specimens from cats and is described on the basis of a study of 39 strains. The newly described species is phenotypically similar to strains of Staphylococcus simulans, but has low levels of deoxyribonucleic acid-deoxyribonucleic acid homology $(<10 \%)$ with $S$. simulans JCM $2424^{\mathrm{T}}$ and related staphylococci. $S$. felis strains were coagulase negative and susceptible to novobiocin and bacitracin. A simple scheme for the differentiation of $S$. felis from related staphylococci is presented. The type strain is strain GD521 (= ATCC 49168 = JCM 7469).
\end{abstract}

Staphylococci have received a great deal of attention, because they cause a large number of infections in humans and animals. They are also one of the major groups of bacteria inhabiting skin. Most research has been carried out with the pathogenic species Staphylococcus aureus, but the pathogenesis of staphylococci is still unclear. In addition, the relationship between staphylococci and their compromised hosts has recently been recognized. In this regard, the systematics of staphylococci has been advanced. In 1975 Kloos and Schleifer presented a new classification of the genus Staphylococcus $(13,29)$. This scheme was based mainly on studies of coagulase-negative strains isolated from humans. Reports on species of human origin have continued $(7,11,15,17)$, and there have also been reports of species of animal origin $(3-5,8,10,27)$ and species from various other sources $(12,25,28)$. On the Approved Lists of Bacterial Names (31), 13 species were listed in the genus Staphylococcus; there are now 27 different Staphylococcus species. Recently, Staphylococcus delphini has been described by Varaldo et al. (34).

In the course of taxonomic studies on staphylococci isolated from dogs and cats, a group of unidentified coagulase-negative strains was discovered. These strains were isolated from infections of cats, but not from infections of dogs (unpublished data). The lesions included external otitis, cystitis, abscesses, wounds, and other skin infections. In this paper we present the results of our taxonomic study of these isolates.

\section{MATERIALS AND METHODS}

Bacterial strains. A total of 39 strains (strains GD3, GD32, GD104, GD113, GD121, GD134, GD140, GD161, GD359, GD371, GD462, GD521 ${ }^{\mathrm{T}}$ [T = type strain], GD523, S5, S31, S36, S111, S141, S143, S169, S173, S194, S203, S273, S336, S345, S365, S370, S379, S408, S410, S425, S426, S459, S463, S476, S504, S518, and S524) were isolated from clinical specimens from cats diagnosed as suffering from external ear otitis, cystitis, abscesses, wounds, and other skin infections between 1982 and 1988. The isolation medium used was horse blood agar (Trypticase soy agar [BBL Microbiology Systems, Cockeysville, Md.] supplemented with 5\% defibrinated horse blood). Trypticase soy agar slants were used for the propagation of all strains. All cultures were maintained at $-80^{\circ} \mathrm{C}$ in skim milk (Difco Laboratories, Detroit, Mich.).

\footnotetext{
* Corresponding author.
}

Unless noted otherwise, inocula for biochemical tests were prepared from overnight cultures on $P$ agar plates (18), and incubation for the tests was done at $37^{\circ} \mathrm{C}$. The type strains (see Tables 2 and 3) of various Staphylococcus species were purchased from the following institutions: Japan Collection of Microorganisms (JCM), Wako Riken, Japan; Czechoslovak Collection of Microorganisms (CCM), Brno, Czechoslovakia; Deutsche Sammlung von Mikroorganismen (DSM), Braunschweig, Federal Republic of Germany; American Type Culture Collection (ATCC), Rockville, Md.; and National Collection of Food Bacteria (NCFB), Reading, United Kingdom.

S. aureus subsp. anaerobius MVF-7 was a generous gift from R. De La Fuente. Staphylococcus schleiferi N850274 and Staphylococcus lugdunensis N860297 were kindly provided by J. Freney.

Morphological and colonial characteristics. Colony morphology and pigmentation were observed on $P$ agar plates by using the method of Kloos et al. (18). Cell morphology was observed with Gram-stained smears.

Physiological characteristics. Anaerobic growth was tested by using the semisolid thioglycolate medium described by Ushioda et al. (33). The optimal growth temperature range and growth at different $\mathrm{NaCl}$ concentrations (7.5, 10, and $15 \%$ ) were estimated by using the methods of Kloos et al. (18).

Biochemical characteristics. Catalase activity was determined by inoculating a small amount of a plate culture into a drop of $3 \% \mathrm{H}_{2} \mathrm{O}_{2}$. Oxidase activity was determined by using the method of Faller and Schleifer (6). The production of free coagulase was tested by using the method of Sperber and Tatini (32) and a 1/4 dilution of fresh heparinized plasma from rabbits, cows, and dogs. Clumping factor was detected with a $1 / 4$ dilution of human plasma. Hemolysis was determined on sheep, human, and rabbit blood soft agar plates as described by Sakazaki (24). Sheep blood agar was used for the hot-cold reaction. Heat-stable nuclease was detected by the microslide method described by Lachica et al. (19).

Hyaluronidase production was estimated as follows: a mucoid Pasteurella multocida strain was spread over the surfaces of Trypticase soy agar plates, and the sample strains were spot inoculated (5). The appearance of zones of nonmucoid colonies surrounding the staphylococcal colonies was taken as an indication of hyaluronidase production.

Acetoin production was determined in $3 \mathrm{ml}$ of a $48-\mathrm{h}$ culture in VP semisolid medium (Eiken Co., Tokyo, Japan) by adding 4 drops of $6 \%$ alpha-naphthol (alcoholic) and 2 
drops of $40 \%$ potassium hydroxide containing $0.3 \%$ creatine. Phosphatase was detected by using phenolphtalein diphosphate medium (21). The sample strains were spot inoculated onto a phenolphthalein diphosphate agar plate, incubated for $24 \mathrm{~h}$, and then exposed to $\mathrm{NH}_{3}$ gas. Nitrate reduction was tested by the sulfanilic acid- $\alpha$-naphthylamine method in $3 \mathrm{ml}$ of MN Nissui medium (Nissui Seiyaku Co., Tokyo, Japan). All negative tests were confirmed by adding zinc dust. Arginine dihydrolase was detected in $3 \mathrm{ml}$ of Moeller decarboxylase base (Difco) containing 1\% L-arginine (Difco Manual, 10th ed., Difco Laboratories, Detroit, Mich., 1984). Urease production was determined in Christensen medium (1).

Enzymatic reactions were detected by using API Zym tests (API System S. A., La Balme les Grottes, France). The configuration of the lactic acids produced was determined with F-kit L-lactic acid (Boehringer Mannheim Biochemicals, Indianapolis, Inc.). Determination of D-lactic acid was made by using $\mathrm{D}$-lactic dehydrogenase (Boehringer Mannheim).

The ability to produce acid from various carbohydrates under aerobic conditions was tested both by the agar plate method (18) and by the broth method, using purple base medium with a final carbohydrate concentration of $1 \%$. Purple base medium had the following composition: $1 \mathrm{~g}$ of beef extract (Difco), $10 \mathrm{~g}$ of Difco Proteose Peptone no. 3, 5 $\mathrm{g}$ of sodium chloride, $10 \mathrm{ml}$ of $0.2 \%$ bromcresol purple, and $1,000 \mathrm{ml}$ of distilled water. The agar plates contained $15 \mathrm{~g}$ of Bacto-Agar (Difco) per liter. The agar plate method was performed and interpreted as described by Kloos et al. (18). For the broth method we used a volume of $1 \mathrm{ml}$, and the final $\mathrm{pH}$ was recorded by using a model BIS-120 bacterial automatic identifier system (Lifetec Co., Tokorozawa, Japan).

Antibiotic susceptibilities. After organisms were subcultured in Eiken susceptibility test broth, cultures were diluted about 100 times with the same medium $\left(10^{6}\right.$ cells per ml). A $20-\mu$ l portion of a bacterial dilution was spot inoculated onto an Eiken susceptibility test agar plate containing $1.6 \mu \mathrm{g}$ of novobiocin per $\mathrm{ml}$ or $2 \mathrm{U}$ of bacitracin per $\mathrm{ml}$, and the preparation was incubated for $48 \mathrm{~h}(9,14)$. Lysostaphin susceptibility was tested as previously described (18). The minimal inhibitory concentrations (MICs) of penicillin G, ampicillin, erythromycin, oxytetracycline, and chloramphenicol were determined by the agar dilution method.

Cell walls. The cell wall peptidoglycan types were determined from the quantitative amino acid compositions by using the method of Schleifer and Kandler (26).

DNA. Lysostaphin (Sigma Chemical Co., St. Louis, Mo.) was used for cell disruption. Deoxyribonucleic acid (DNA) was isolated as described by Saito and Miura (23). The guanine-plus-cytosine content of DNA was determined by the thermal denaturation method of Marmur and Doty (22). Native DNA was labeled with $\left[{ }^{3} \mathrm{H}\right]$ deoxycytidine triphosphate by using a nick translation kit (kit N.5500; Amersham International plc, Buckinghamshire, United Kingdom). DNA-DNA hybridization experiments were performed by using the $S 1$ digestion method (2). Hot and cold DNAs were mixed and hybridized for $24 \mathrm{~h}$ at $58^{\circ} \mathrm{C}$.

\section{RESULTS AND DISCUSSION}

Physiological and biochemical characteristics. The characteristics of 39 strains of Staphylococcus felis are shown in Table 1. Except for the arginine reaction and some carbohydrate reactions, the 39 strains were homogeneous. All of the strains were coagulase negative and susceptible to no-
TABLE 1. Characteristics of $S$. felis strains and type strain GD521 ${ }^{a}$

\begin{tabular}{|c|c|c|}
\hline Test & $\begin{array}{c}\text { No. of } \\
\text { strains positive } \\
(n=39)\end{array}$ & $\begin{array}{l}\text { S. felis } \\
\text { GD521 }^{\mathrm{T}}\end{array}$ \\
\hline Colony pigment & 0 & - \\
\hline Colony diam $>5 \mathrm{~mm}$ & 39 & + \\
\hline Anaerobic growth (thioglycolate medium) & 39 & + \\
\hline Tube coagulase (rabbit plasma) & 0 & - \\
\hline Clumping factor (human plasma) & 0 & - \\
\hline Hyaluronidase & 0 & - \\
\hline Heat-stable nuclease & $0^{b}$ & - \\
\hline Acetoin production & 0 & - \\
\hline Oxidase & 0 & - \\
\hline Phosphatase & 39 & + \\
\hline Nitrate reduction & 39 & + \\
\hline Arginine dihydrolase & 36 & + \\
\hline Urease & 39 & + \\
\hline Novobiocin resistance (MIC, $\geqq 1.6 \mu \mathrm{g} / \mathrm{ml}$ ) & 0 & - \\
\hline Bacitracin resistance $(2 \mathrm{U} / \mathrm{ml})$ & 0 & - \\
\hline \multicolumn{3}{|l|}{ Acid produced aerobically from: } \\
\hline Xylose & 0 & - \\
\hline Arabinose & 0 & - \\
\hline Cellobiose & 0 & - \\
\hline Raffinose & 0 & - \\
\hline Sucrose & 26 & - \\
\hline Maltose & 0 & - \\
\hline Mannitol & 34 & + \\
\hline Mannose & 39 & + \\
\hline Trehalose & 39 & + \\
\hline Lactose & 39 & + \\
\hline Galactose & $30^{c}$ & + \\
\hline Ribose & 8 & - \\
\hline Xylitol & 0 & - \\
\hline Glycerol & 39 & + \\
\hline
\end{tabular}

${ }^{a}$ The peptidoglycan structure of the type strain is of the L-Lys-Gly $4.5-\mathrm{Ser}_{0.5}$ type.

${ }_{b}^{b}$ The results of a heat-stable nuclease production test indicated negative or very weak reactions in all strains.

${ }^{c}$ Weak or delayed reactions occur in some strains.

vobiocin, bacitracin, or lysostaphin. Heat-stable nuclease was negative or very weakly produced.

DNA-DNA hybridization. The DNA relatedness results obtained with labeled DNA from $S$. felis GD521 ${ }^{\mathrm{T}}$ are summarized in Table 2. All six strains of $S$. felis tested exhibited high levels of homology $(>80 \%)$ with each other, whereas the levels of DNA homology between these strains and other staphylococci were rather low (1 to $9 \%$ ).

DNA base composition. The average base composition of $S$. felis strains was 35 mol\% guanine plus cytosine.

Description of Staphylococcus felis sp. nov. Staphylococcus felis (fe' lis. L. gen. n. felis, of a cat). The description of $S$. felis below is based on 39 strains, unless otherwise noted. Cells are gram-positive cocci (diameter, 0.8 to $1.2 \mu \mathrm{m}$ ) that occur singly, in pairs, and predominantly in irregular clusters. Nonmotile. Nonsporeforming. Agar colonies are circular, entire, 5.0 to $8.0 \mathrm{~mm}$ in diameter, slightly convex, and opaque with smooth and glistening surfaces. Most strains are unpigmented. Facultatively anaerobic. Growth occurs in both the aerobic and anaerobic portions of thioglycolate medium. These organisms grow in the presence of $10 \%$ (wt/vol) $\mathrm{NaCl}$ in $\mathrm{P}$ agar after $24 \mathrm{~h}$ and in the presence of $15 \%$ $\mathrm{NaCl}$ after $72 \mathrm{~h}$. They grow weakly at $45^{\circ} \mathrm{C}$ and very weakly at $15^{\circ} \mathrm{C}$. Biochemical characteristics are listed in Table 1 . All of the strains produce neither free coagulase nor fixed coagulase (clumping factor). All strains fail to produce $\beta$-hemolysin (hemolysis on sheep blood agar and hot-cold 
TABLE 2. Levels of DNA-DNA relatedness between $S$. felis and other species in the genus Staphylococcus

\begin{tabular}{|c|c|}
\hline Source of unlabeled DNA & $\begin{array}{l}\% \text { Relatedness with } \\
\text { S. felis GD521 }\end{array}$ \\
\hline S. felis GD521 ${ }^{\mathrm{T}}$ & $100^{a}$ \\
\hline S. felis GD32 & 91 \\
\hline S. felis GD104 & 81 \\
\hline S. felis GD121 & 93 \\
\hline S. felis $\mathrm{S} 36$ & 84 \\
\hline S. felis S141 & 84 \\
\hline S. aureus subsp. aureus $\mathrm{CCM} 885^{\mathrm{T}}$ & 4 \\
\hline S. aureus subsp. anaerobius MVF-7 & 6 \\
\hline S. intermedius JCM $2422^{\mathrm{T}}$ & 9 \\
\hline S. hyicus JCM $2423^{\mathrm{T}}$ & 5 \\
\hline S. chromogenes CCM $3387^{\mathrm{T}}$ & 9 \\
\hline S. epidermidis JCM $2414^{\mathrm{T}}$ & 3 \\
\hline S. saprophyticus JCM $2427^{\mathrm{T}}$ & 2 \\
\hline S. simulans $\mathrm{JCM} 2424^{\mathrm{T}}$ & 6 \\
\hline S. simulans GC262 & 4 \\
\hline S. sciuri ATCC $29062^{\mathrm{T}}$ & 4 \\
\hline S. lentus ATCC $29070^{\mathrm{T}}$ & 5 \\
\hline S. xylosus JCM $2418^{\mathrm{T}}$ & 4 \\
\hline S. cohnii JCM $2417^{\mathrm{T}}$ & 2 \\
\hline S. capitis JCM $2420^{\mathrm{T}}$ & 3 \\
\hline S. hominis JCM $2419^{\mathrm{T}}$ & 2 \\
\hline S. hemolyticus JCM $2416^{\mathrm{T}}$ & 3 \\
\hline S. warneri JCM $2415^{\mathrm{T}}$ & 6 \\
\hline S. carnosus DSM $20501^{\mathrm{T}}$ & 4 \\
\hline S. caseolyticus ATCC $13548^{\text {T }}$ & 5 \\
\hline S. auricularis ATCC $33753^{\mathrm{T}}$ & 8 \\
\hline S. gallinarum CCM $3572^{\mathrm{T}}$ & 4 \\
\hline S. caprae CCM $3573^{\mathrm{T}}$ & 3 \\
\hline S. saccharolyticus NCFB 1260 & 7 \\
\hline S. arlettae DSM $20672^{\mathrm{T}}$ & 7 \\
\hline S. equorum DSM $20674^{\mathrm{T}}$ & 6 \\
\hline S. kloosii DSM $20676^{\mathrm{T}}$ & 5 \\
\hline$S$. lugdunensis N860297 ${ }^{\mathrm{T}}$ & 1 \\
\hline S. schleiferi $\mathrm{N} 850274^{\mathrm{T}}$ & 9 \\
\hline
\end{tabular}

${ }^{a}$ Level of relatedness after reassociation for $24 \mathrm{~h}$ at $58^{\circ} \mathrm{C}$. reaction). Typical $\alpha$-hemolysin and $\delta$-hemolysin are not detected, but most strains have very weak hemolytic activity. All strains are susceptible to novobiocin $(1.6 \mu \mathrm{g} / \mathrm{ml})$, bacitracin $(2 \mathrm{U} / \mathrm{ml})$, and lysostaphin $(200 \mu \mathrm{g} / \mathrm{ml})$. All strains produce acid from glucose, mannose, fructose, trehalose, lactose, and glycerol. Acid is usually produced from mannitol ( $87 \%$ of the strains), galactose ( $77 \%$ of the strains), and sucrose $(67 \%$ of the strains); some strains produce acid from ribose ( $21 \%$ of the strains). No acid is produced from arabinose, xylose, maltose, cellobiose, raffinose, or xylitol by the 39 strains which we tested; no acid is produced from melibiose, rhamnose, melezitose, glycogen, sorbitol, erythritol, inositol, adonitol, dulcitol, dextrin, salicin, or amygdalin by 22 of the strains which we tested. All six strains tested produce esterase (C4), esterase lipase $(\mathrm{C} 8)$, and $\beta$-galactosidase. Most strains (four of five strains tested) weakly produce lipase and $\alpha$-glucosidase. The following enzymes are not detected: leucine arylamidase, valine arylamidase, cystine arylamidase, trypsin, chymotrypsin, $\alpha$-galactosidase, $\beta$-glucuronidase, $\beta$-glucosidase, $N$-acetyl- $\beta$-glucosamidase, $\alpha$-mannosidase, and $\beta$-fucosidase. All 12 strains tested are highly susceptible to penicillin G (MIC, $<0.025$ to $0.1 \mu \mathrm{g} / \mathrm{ml}$ ) and ampicillin (MIC, $<0.1 \mu \mathrm{g} / \mathrm{ml}$ ). All strains are susceptible to erythromycin $(0.2$ to $0.39 \mu \mathrm{g} / \mathrm{ml})$ and chloramphenicol (3.13 to $6.25 \mu \mathrm{g} / \mathrm{ml})$. Most strains are susceptible to oxytetracycline $(0.39$ to $0.78 \mu \mathrm{g} / \mathrm{ml})$; one strain which we tested is resistant to this antibiotic (MIC, $100 \mu \mathrm{g} / \mathrm{ml})$.

Description of the type strain. Type strain GD521 was isolated from a mass on the auricle of a cat. The characteristics of type strain GD521 are the same as those described above and listed in Table 1 . Strain GD521 ${ }^{\mathrm{T}}$ produces only L-lactic acid from glucose. The peptidoglycan structure is of the L-Lys-Gly ${ }_{4.6}-\mathrm{Ser}_{0.5}$ type. The guanine-plus-cytosine content of its DNA as determined by the melting temperature method is $35.2 \mathrm{~mol} \%$.

Characteristics which differentiate $S$. felis from other related staphylococcal species. Selected characteristics that are useful in the identification of $S$. felis and in separation of this

TABLE 3. Characteristics differentiating $S$. felis sp. nov. from other novobiocin-susceptible Staphylococcus species $^{a}$

\begin{tabular}{|c|c|c|c|c|c|c|c|c|c|c|c|c|c|c|c|c|c|c|}
\hline Characteristic & $\underset{\dot{s}}{\stackrel{3}{*}}$ & 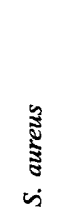 & 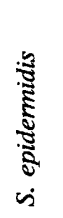 & 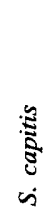 & 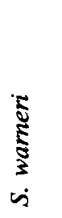 & 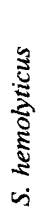 & 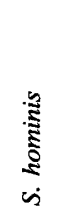 & 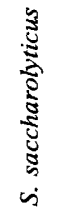 & 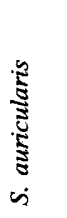 & 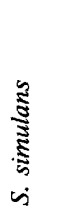 & 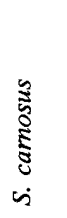 & 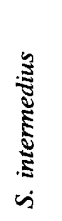 & 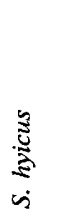 & 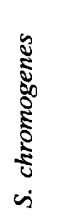 & 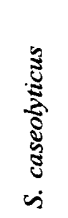 & 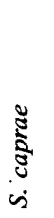 & 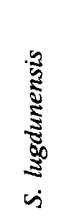 & 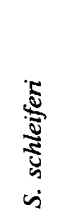 \\
\hline Colony diam $>5 \mathrm{~mm}$ & $t^{b}$ & + & - & - & $\mathrm{d}$ & + & - & - & - & + & + & + & + & + & - & $\mathrm{d}$ & - & - \\
\hline Pigment & - & $+w$ & - & - & $\mathrm{d}$ & d & $\mathrm{d}$ & - & - & - & - & - & - & + & d & - & $\mathrm{d}$ & - \\
\hline Oxidase test & - & - & - & - & - & - & - & - & - & - & - & - & - & - & + & - & - & - \\
\hline Alkaline phosphatase & + & + & + & - & - & - & - & ND & - & $\mathbf{w}$ & + & + & + & + & ND & + & - & + \\
\hline Urease & + & $+w$ & + & - & + & - & + & ND & - & + & - & + & $\mathrm{d}$ & $\mathrm{d}$ & ND & + & ND & ND \\
\hline Coagulase (rabbit plasma) & - & + & - & - & - & - & - & - & - & - & - & + & $\mathrm{d}$ & - & - & - & - & - \\
\hline Acid produced aerobically from: & & & & & & & & & & & & & & & & & & \\
\hline Sucrose & d & + & + & $(+)$ & + & + & $(+)$ & - & $\mathrm{d}$ & + & - & + & + & + & d & - & + & - \\
\hline Maltose & - & + & + & - & $(+)$ & + & + & - & $(+)$ & $-\mathbf{w}$ & - & $(\mathbf{w})$ & - & d & + & d & + & - \\
\hline Mannitol & $\mathrm{d}$ & + & - & + & $\mathrm{d}$ & d & - & - & - & + & + & (d) & - & $\mathrm{d}$ & - & $\mathrm{d}$ & - & - \\
\hline Mannose & + & + & $(+)$ & + & - & - & - & $(+)$ & - & d & + & + & + & + & - & + & + & + \\
\hline Trehalose & + & + & - & - & + & + & d & - & $(+)$ & d & d & + & + & + & d & + & + & d \\
\hline Ribose & $-w$ & + & d & - & $\mathrm{d}$ & d & - & ND & - & d & ND & + & + & + & + & - & - & - \\
\hline $\begin{array}{l}\text { Bacitracin resistance } \\
(\mathrm{MIC}, \geqq 2 \mathrm{U} / \mathrm{ml})^{c}\end{array}$ & - & + & + & + & - & - & - & ND & + & + & + & + & + & - & - & + & + & + \\
\hline
\end{tabular}

\footnotetext{
a Data from references 7 and 16

$b+, 90 \%$ or more of the strains are positive;,$- 90 \%$ or more of the strains are negative; $d, 11$ to $89 \%$ of the strains are positive; $w$, weak reaction; $-w$, negative to weak reaction; $+w$, positive to weak reaction; ND, not determined. Parentheses indicate a delayed reaction.

c Data from this study (reactions of type strains).
} 
taxon from other novobiocin-susceptible staphylococcal species are shown in Table $3 . S$. felis is easily differentiated from coagulase-positive species by a negative coagulase test and very weak deoxyribonuclease production. Except for Staphylococcus simulans, $S$. felis can be distinguished from the other coagulase-negative staphylococci by its biochemical reactions shown in Table 3 . It is difficult to distinguish between $S$. felis and $S$. simulans by their biochemical properties. The biochemical characteristics of $S$. felis are very similar to those of $S$. simulans, and we are afraid that $S$. felis strains have been misidentified as $S$. simulans. Bacitracin susceptibility is a useful property for distinguishing $S$. felis from $S$. simulans. All $10 S$. simulans strains which we examined were resistant to $2 \mathrm{U}$ of bacitracin (MIC, $8.8 \pm 4.1$ $\mathrm{U} / \mathrm{ml}$ ), but all $14 \mathrm{~S}$. felis strains were susceptible to $2 \mathrm{U}$ of bacitracin (MIC, $0.45 \pm 0.20 \mathrm{U} / \mathrm{ml}$ ). In addition, when we studied the strains isolated from dogs and cats, all of the $S$. felis strains produced acid from mannose, but the $S$. simulans strains did not. For the strains isolated from dogs and cats, the production of acid from mannose was a useful property. However, this characteristic is not suitable for identifying strains isolated from various sources, because Kloos and Schleifer (13) reported that many strains of $S$. simulans $(>60 \%)$ were mannose positive.

\section{ACKNOWLEDGMENTS}

We are greatly indebted to Hisae Atobe, Tomohiko Fujisawa, Akira Inoue, and Ken-ichiro Suzuki for their excellent technical advice and assistance throughout this study.

\section{LITERATURE CITED}

1. Christensen, W. B. 1946. Urea decomposition as a means of differentiating Proteus and Paracolon cultures from each other and from Salmonella and Shigella types. J. Bacteriol, 52: $461-466$.

2. Crosa, J., H. Braener, and S. Falkow. 1973. Use of a singlestrand-specific nuclease for analysis of bacterial and plasmid deoxyribonucleic acid homo- and heteroduplexes. J. Bacteriol. 115:904-911.

3. Devriese, L. A. 1977. Isolation and identification of Staphylococcus hyicus. Am. J. Vet. Res. 38:787-792.

4. Devriese, L. A., V. Hajek, P. Oeding, S. A. Meyer, and K. H. Schleifer. 1978. Staphylococcus hyicus (Sompolinsky 1953) comb. nov. and Staphylococcus hyicus subsp. chromogenes subsp. nov. Int. J. Syst. Bacteriol. 28:482-490.

5. Devriese, L. A., B. Poutrel, R. Kilpper-Balz, and K. H. Schleifer. 1983. Staphylococcus gallinarum and Staphylococcus caprae, two new species from animals. Int. J. Syst. Bacteriol. 33: $480-486$.

6. Faller, A., and K. H. Schleifer. 1981. Modified oxidase and benzidine tests for separation of staphylococci from micrococci. J. Clin. Microbiol. 13:1031-1035.

7. Freney, J., Y. Brun, M. Bes, H. Meugnier, F. Grimont, P. A. D. Grimont, C. Nervi, and J. Fleurette. 1988. Staphylococcus lugdunensis sp. nov. and Staphylococcus schleiferi sp. nov., two species from human clinical specimens. Int. J. Syst. Bacteriol. 38:168-172.

8. Fuente, R. D. L., G. Suarez, and K. H. Schleifer. 1985. Staphylococcus aureus subsp. anaerbius subsp. nov., the causal agent of abscess disease of sheep. Int. J. Syst. Bacteriol. 35:99-102.

9. Goldstein, J., R. Schulman, E. Kelley, G. McKinley, and J. Fung. 1983. Effect of different media on determination of novobiocin resistance for differentiation of coagulase-negative staphylococci. J. Clin. Microbiol. 18:592-595.

10. Hajek, V. 1976. Staphylococcus intermedius, a new species isolated from animals. Int. J. Syst. Bacteriol. 26:401-408.

11. Hugh, R., and M. A. Ellis. 1968. The neotype strain for
Staphylococcus epidermidis (Winslow and Winslow 1908) Evens 1916. Int. J. Syst. Bacteriol. 18:231-239.

12. Kilpper-Balz, R., and K. H. Schleifer. 1981. Transfer of Peptococcus saccharolyticus Foubert and Douglas to the genus Staphylococcus: Staphylococcus saccharolyticus (Foubert and Douglas) comb. nov. Zentralbl. Bakteriol. Parasitenkd. Infektionskr. Hyg. Abt. 1 Orig. 2:324-331

13. Kloos, W. E., and K. H. Schleifer. 1975. Isolation and characterization of staphylococci from human skin. II. Descriptions of four new species: Staphylococcus warneri, Staphylococcus capitis, Staphylococcus hominis, and Staphylococcus simulans. Int. J. Syst. Bacteriol. 25:62-79.

14. Kloos, W. E., and K. H. Schleifer. 1975. Simplified scheme for routine identification of human Staphylococcus species. J. Clin. Microbiol. 1:82-88.

15. Kloos, W. E., and K. H. Schleifer. 1983. Staphylococcus auricularis sp. nov.: an inhabitant of the human external ear. Int. J. Syst. Bacteriol. 33:9-14.

16. Kloos, W. E., and K. H. Schleifer. 1986. Genus IV. Staphylococcus Rosenbach $1884,18^{\mathrm{AL}}$, (Nom. Cons. Opin. $17 \mathrm{Jud}$ Comm. 1958, 153), p. 1013-1035. In P. H. A. Sneath, N. S. Mair, M. E. Sharpe, and J. G. Holt (ed.), Bergey's manual of systematic bacteriology, vol. 2. The Williams \& Wilkins Co., Baltimore.

17. Kloos, W. E., K. H. Schleifer, and R. F. Smith. 1976. Characterization of Staphylococcus sciuri sp. nov. and its subspecies. Int. J. Syst. Bacteriol. 26:22-37.

18. Kloos, W. E., T. G. Tornabene, and K. H. Schleifer. 1974. Isolation and characterization of micrococci from human skin, including two new species: Micrococcus lylae and Micrococcus kristinae. Int. J. Syst. Bacteriol. 24:79-101.

19. Lachica, R. V. F., C. Genigeorgis, and P. D. Hoeprich. 1974. Metachromatic agar-difusion methods for detecting staphylococcal nuclease activity. Appl. Microbiol. 21:585-587.

20. Lennette, E. H. 1980. Manual of clinical microbiology, 3th ed. American Society for Microbiology, Washington, D.C.

21. MacFaddin, J. F. 1980. Biochemical tests for identification of medical bacteria, 2nd ed. The Williams \& Wilkins Co., Baltimore.

22. Marmur, J., and P. Doty. 1962. Determination of the base composition of deoxyribonucleic acid from its thermal denaturation temperature. J. Mol. Biol. 5:109-118.

23. Saito, H., and K. Miura. 1963. Preparation of transforming deoxyribonucleic acid by phenol treatment. Biochim. Biophys. Acta 72:619-629.

24. Sakazaki, R. 1980. Bacterial culture media. Kindai Shuppan Co., Tokyo. (In Japanese).

25. Schleifer, K. H., and U. Fischer. 1982. Description of a new species of the genus Staphylococcus: Staphylococcus carnosus. Int. J. Syst. Bacteriol. 32:153-156.

26. Schleifer, K. H., and O. Kandler. 1972. Peptidoglycan types of bacterial cell walls and their taxonomic implications. Bacteriol. Rev. 36:407-477.

27. Schleifer, K. H., R. Kilpper-Balz, and L. A. Devriese. 1984. Staphylococcus arlettae sp. nov., $S$. equorum sp. nov. and $S$. kloosii sp. nov.: three new coagulase-negative, novobiocinresistant species from animals. Syst. Appl. Microbiol. 5:501509.

28. Schleifer, K. H., R. Kilpper-Balz, U. Fischer, A. Faller, and J. Endl. 1982. Identification of "Micrococcus candidus" ATCC 14852 as a strain of "Micrococcus caseolyticus" ATCC 13548 and Micrococcus varians ATCC 29750 as members of a new species, Staphylococcus caseolyticus. Int. J. Syst. Bacteriol. 32:15-20.

29. Schleifer, K. H., and W. E. Kloos. 1975. Isolation and characterization of staphylococci from human skin. I. Amended descriptions of Staphylococcus epidermidis and Staphylococcus saprophyticus and descriptions of three new species: Staphylococcus cohnii, Staphylococcus haemolyticus, and Staphylococcus xylosus. Int. J. Syst. Bacteriol. 25:50-61.

30. Schleifer, K. H., and M. Kocur. 1973. Clasification of staphylococci based on chemical and biochemical properties. Arch. Mikrobiol. 93:65-85. 
31. Skerman, V. B. D., V. McGowan, and P. H. A. Sneath (ed.). 1980. Approved lists of bacterial names. Int. J. Syst. Bacteriol. 30:225-420.

32. Sperber, W. H., and S. R. Tatini. 1975. Interpretation of the tube coagulase test for identification of Staphylococcus aureus. Appl. Microbiol. 29:502-505.

33. Ushioda, H., A. Tsuji, M. Ogawa, S. Goto, and S. Sakai. 1980. A medium for the rapid glucose fermentation test to distinguish coagulase-negative staphylococci from micrococci. Jpn. J. Bacteriol. 35:753-763. (In Japanese.)

34. Varaldo, P. E., R. Kilpper-Balz, F. Biavasco, G. Satta, and K. H. Schleifer. 1988. Staphylococcus delphini sp. nov., a coagulasepositive species isolated from dolphins. Int. J. Syst. Bacteriol. 38:436-439. 